\title{
Non-syndromic pheochromocytoma: From post-operatory scores to lifetime follow-up
}

\author{
Mihai Cristian DUMITRASCU ${ }^{1,2}$, Diana Elena BECHERU ${ }^{3}$, Eugenia PETROVA ${ }^{1,3}$, Anda DUMITRASCU ${ }^{3}$, \\ Adina GHEMIGIAN ${ }^{1,3}$, Mara CARSOTE ${ }^{1,3}$, Mihaela POPESCU ${ }^{5}$, Florica SANDRU ${ }^{1,4}$ \\ 1"Carol Davila" University of Medicine and Pharmacy, Bucharest, Romania \\ 2University Emergency Hospital, Bucharest, Romania \\ 3"C.I. Parhon" National Institute of Endocrinology, Bucharest, Romania \\ ${ }^{4}$ Elias Emergency Hospital, Bucharest, Romania \\ ${ }^{5}$ Craiova University of Medicine and Pharmacy, Craiova, Romania
}

\section{ABSTRACT}

We introduce a case report of an adult male diagnosed with non-syndromic pheochromocytoma with a first pathological post-operatory report of malignant type with further re-considerations during follow-up for a 6-year period of time. This is 46 - year old male admitted for: post-adrenalectomy status reassessment. In 2013 he was diagnosed with high blood pressure requiring a complex regime of anti-hypertensive drugs to control it. In 2015 he was referred for an endocrine check-up which revealed a pheochromocytoma (noradrenaline type). Computed tomography imaging of the abdomen showed a right adrenal tumour of 28/38 $\mathrm{mm}$, a mass that was clearly contoured, with heterogeneous pattern, and with moderate caption of intravenous contrast. Laparoscopic right adrenalectomy is performed with normalization of high pre-operatory normetanephrines and a dose reduction of anti-hypertensive medication which was still necessary. Pathological report suggested a malignant pheochromocytoma; the initial PASS score of 8 was later re-calculated, and a GAPP score of 5 was achieved showing a moderately differentiated tumour. No genetic backup was identified. Within the first year after tumour removal, the patient suffered a stroke, proving the higher cardiovascular risk than general population even after hormonal imbalance is restored. Lifelong surveillance is the rule.
\end{abstract}

Keywords: pheochromocytoma, adrenalectomy, high blood pressure, PASS score, GAPP score, stroke

\section{INTRODUCTION}

There are multiple endocrine causes of high blood pressure like pituitary related causes (acromegaly, Cushing disease), adrenal-related causes (like pheochromocytoma, Conn's syndrome, adrenal Cushing syndrome, certain types of bilateral macronodular hyperplasia, adrenocortical carcinoma, etc.), some thyroid conditions, especially those with hyper-function or overtreatment with levothyroxine, and, also particular types of neuroendocrine neoplasia (1-5). Pheochromocytoma is a rare, yet potentially deadly condition, due to increased cardiovascular risk, as well as potential malignant status in some cases as shown by high GAPP/ PASS scores $(6,7)$. Malignant pheochromocytoma, however, is traditionally considered if the positive metastatic status is found $(8,9)$. Despite progress in early 
approach and advanced imaging like 68Ga-DOTATATE and 64Cu-DOTATATE, pheochromocytoma has usually a strong genetic background, and the potential of aggressive profile remains an open issue, thus lifelong surveillance is indicated in majority of cases $(10,11)$.

\section{AIM}

We introduce a case report of an adult male diagnosed with non-syndromic pheochromocytoma with a first pathological report of malignant type with further considerations during follow-up. The patient agreed to use the medical records, respecting the anonymous presentation.

\section{CASE PRESENTATION}

This is 46 - year old male admitted for: post-adrenalectomy status reassessment. His medical family history is negative.

The personal medical history includes:

- 2013: diagnostic of high blood pressure at Cardiology Department. Anamnesis showed that the patient had paroxysmal hypertension with the highest values of $220 / 120 \mathrm{mmHg}$, with palpitations, intensive sweating, muscle weakness, pallor, tachypnea. The patient started antihypertensive treatment with modest control of arterial pressure values: Metoprolol $50 \mathrm{mg} /$ day; Pentaeritril Tetranitrate $2.6 \mathrm{mg}$ (1-0-0); Trimetazidine 20 mg (0-1-0); Perindopril 10 mg (0-0-1); Indapamide $2.5 \mathrm{mg}(0-0-1)$

- 2013-2015: anamnesis revealed paroxysmal hypertension under antihypertensive treatment (different regimes were taken into consideration)

- June 2015: recommendation for an endocrine check-up since a secondary endocrine cause is suspected. On admission, the endocrine evaluation confirmed a pheochromocytoma apparently of sporadic type with predominant secretion of normetanephrines opposite to metanephrines (Table 1). Computed tomography imaging of the abdomen and pelvis showed a right adrenal tumour of $28 / 38 \mathrm{~mm}$, a mass that is clearly contoured, with heterogeneous pattern, and with moderate caption of intravenous contrast.

- July 2015: laparoscopic right adrenalectomy (with typical pre-operatory preparation consisting in alpha and beta adrenergic blockage and calcium blockers) went without adverse events. Postoperatively, the patient had a satisfactory evolution, with fast resumption of intestinal transit and per primam healing of surgical wounds. Arterial hypertension was control after adrenalectomy allowing the reduction of antihypertensive mediation without actually stopping it. Three months after adrenalectomy, computed tomography showed a mild fibrous pericarditis and a right kidney stone. Periodical computed tomography scans were used for sequential follow-up (Figure 1).

- The patient was followed for another 6 years, without the confirmation of relapse or metastases. He remained hypertensive. No other endocrine condition was confirmed during surveillance (Tables 2 and 3).

TABLE 1. Endocrine panel before and after adrenalectomy on an adult male with high blood pressure which was related to a nonsyndromic pheochromocytoma

\begin{tabular}{|c|c|c|c|c|c|c|c|c|c|c|}
\hline Parameter & $\begin{array}{l}\text { June } \\
2015 \\
\end{array}$ & \multirow{10}{*}{ 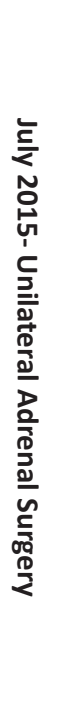 } & 2016 & 2017 & 2018 & 2019 & 2020 & Value & $\begin{array}{c}\text { Normal } \\
\text { ranges }\end{array}$ & Units \\
\hline Plasma metanephrines & 11.9 & & 10.8 & 15.4 & 22.5 & 13.6 & 17.5 & 21.5 & $10-90$ & $\mathrm{pg} / \mathrm{ml}$ \\
\hline Plasma normetanephrines & 1945 & & 23 & 42.3 & 52 & 51 & 46.7 & 56.5 & $15-180$ & $\mathrm{pg} / \mathrm{ml}$ \\
\hline $\begin{array}{l}\text { 24-hour urinary } \\
\text { metanephrines }\end{array}$ & 80.56 & & 90.6 & 94 & 98.7 & 110 & 92 & 53.72 & $50-350$ & $\mu \mathrm{g} / 24 \mathrm{~h}$ \\
\hline $\begin{array}{l}\text { 24-hour urinary } \\
\text { normetanephrines }\end{array}$ & 2935 & & 152 & 116 & 123.4 & 175 & 110 & 317.73 & $100-600$ & $\mu \mathrm{g} / 24 \mathrm{~h}$ \\
\hline Plasma aldosterone & 112 & & 120 & 154.3 & 120.4 & 136 & 210 & 115 & $40-310$ & $\mathrm{pg} / \mathrm{ml}$ \\
\hline Plasma renin & 43.8 & & 25.4 & 23.3 & 18 & 20.3 & 17.6 & 2.78 & 2.64-27.66 & $\mathrm{ng} / \mathrm{ml}$ \\
\hline Cromogranin A & 717.7 & & 63.2 & 50.4 & 53.2 & 70.5 & 68 & 78.2 & 20-100 & $\mathrm{ng} / \mathrm{ml}$ \\
\hline Fasting glycaemia & 82 & & 94 & 98 & 102 & 87 & 88 & 9.3 & $8.5-10.2$ & $\mathrm{mg} / \mathrm{dl}$ \\
\hline $\begin{array}{l}\text { HbA1C (glycated } \\
\text { hemoglobin) }\end{array}$ & 7.5 & & 5.1 & 5.2 & 4.9 & 4.9 & 5 & 24.7 & $30-100$ & $\mathrm{ng} / \mathrm{ml}$ \\
\hline
\end{tabular}




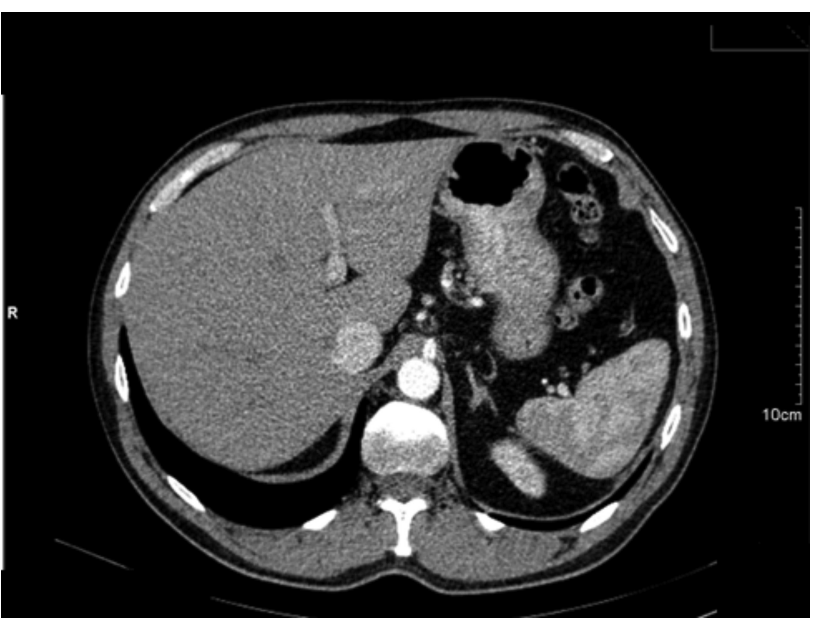

FIGURE 1. Computed tomography of the abdomen on an adult male patient after a right adrenal pheochromocytoma was removed

TABLE 2. The biochemistry panel 6 year after adrenalectomy during follow-up of a male diagnosed with pheochromocytoma

\begin{tabular}{|l|c|c|c|}
\hline Parameter & Value & Normal ranges & Units \\
\hline Uric acid & 2.3 & $3.5-8.5$ & $\mathrm{mg} / \mathrm{dl}$ \\
\hline ALT & 28 & $0-55$ & $\mathrm{U} / \mathrm{L}$ \\
\hline AST & 17 & $5-34$ & $\mathrm{U} / \mathrm{L}$ \\
\hline Ionic calcium & 4.23 & $3.9-4.9$ & $\mathrm{mg} / \mathrm{dl}$ \\
\hline Total serum calcium & 9.3 & $8.5-10.2$ & $\mathrm{mg} / \mathrm{dl}$ \\
\hline cholesterol & 193 & $0-200$ & $\mathrm{mg} / \mathrm{dl}$ \\
\hline Alkaline phosphatase & 58 & $38-129$ & $\mathrm{U} / \mathrm{L}$ \\
\hline Serum phosphorus & 3.5 & $2.3-4.7$ & $\mathrm{mg} / \mathrm{dl}$ \\
\hline Fasting glycaemia & 82 & $70-105$ & $\mathrm{mg} / \mathrm{dl}$ \\
\hline HDL-cholesterol & 61 & $40-60$ & $\mathrm{mg} / \mathrm{dl}$ \\
\hline LDL-cholesterol & 122.4 & $60-160$ & $\mathrm{mg} / \mathrm{dl}$ \\
\hline Potassium & 4.1 & $3.5-5.1$ & $\mathrm{mmol} / \mathrm{L}$ \\
\hline Magnesium & 1.9 & $1.6-2.4$ & $\mathrm{mg} / \mathrm{dl}$ \\
\hline Sodium & 143 & $136-145$ & $\mathrm{mmol} / \mathrm{L}$ \\
\hline Total proteins & 6.8 & $6.5-8.7$ & $\mathrm{~g} / \mathrm{dl}$ \\
\hline Triglycerides & 48 & $50-200$ & $\mathrm{mg} / \mathrm{dl}$ \\
\hline Urea & 39 & $15-50$ & $\mathrm{mg} / \mathrm{dl}$ \\
\hline Creatinine & 0.75 & $0.6-1.3$ & $\mathrm{mg} / \mathrm{dl}$ \\
\hline
\end{tabular}

TABLE 3. Endocrine panel 6 year after pheochromocytoma removal on a 46-year old hypertensive man

\begin{tabular}{|l|c|c|c|}
\hline Parameter & Value & $\begin{array}{c}\text { Normal } \\
\text { ranges }\end{array}$ & Units \\
\hline Plasma metanephrines & 21.5 & $10-90$ & $\mathrm{pg} / \mathrm{ml}$ \\
\hline Plasma normetanephrines & 56.5 & $15-180$ & $\mathrm{pg} / \mathrm{ml}$ \\
\hline $\begin{array}{l}\text { 24-hour urinary } \\
\text { metanephrines }\end{array}$ & 53.72 & $50-350$ & $\mu \mathrm{g} / 24 \mathrm{~h}$ \\
\hline $\begin{array}{l}\text { 24-hour urinary } \\
\text { normetanephrines }\end{array}$ & 317.73 & $100-600$ & $\mu \mathrm{g} / 24 \mathrm{~h}$ \\
\hline $\begin{array}{l}\text { 24-hour urinary } \\
\text { 5-hydroxyindolacetic (5HIIA) }\end{array}$ & 6.35 & $1-10$ & $\mathrm{mg} / 24 \mathrm{~h}$ \\
\hline plasma aldosterone & 115 & $40-310$ & $\mathrm{pg} / \mathrm{ml}$ \\
\hline plasma renin (clinostatism) & 12.78 & $2.64-27.66$ & $\mathrm{ng} / \mathrm{ml}$ \\
\hline $\begin{array}{l}\text { ACTH (adrenocorticotropic } \\
\text { hormone) }\end{array}$ & 60.9 & $3-66$ & $\mathrm{pg} / \mathrm{ml}$ \\
\hline Morning plasma cortisol & 14.81 & $6.2-19.4$ & $\mu \mathrm{g} / \mathrm{dl}$ \\
\hline
\end{tabular}

\begin{tabular}{|l|c|c|c|}
\hline Parameter & Value & $\begin{array}{c}\text { Normal } \\
\text { ranges }\end{array}$ & Units \\
\hline $\begin{array}{l}\text { Morning plasma cortisol } \\
\text { after } 1 \text { mg dexamethasone } \\
\text { suppression test }\end{array}$ & 1.15 & $<1.8$ & $\mu \mathrm{g} / \mathrm{dl}$ \\
\hline 24-urinary free cortisol & 201.85 & $58-403$ & $\mu \mathrm{g} / 24 \mathrm{~h}$ \\
\hline Cromogranin A & 78.2 & $20-100$ & $\mathrm{ng} / \mathrm{ml}$ \\
\hline Serum serotonine & 121.8 & $80-400$ & $\mathrm{ng} / \mathrm{ml}$ \\
\hline Neuron specific enolase & 8.31 & $0-12$ & $\mathrm{ng} / \mathrm{ml}$ \\
\hline $\begin{array}{l}\text { TSH (thyroid stimulating } \\
\text { hormone) }\end{array}$ & 2.43 & $0.5-4.5$ & $\mu \mathrm{Ul} / \mathrm{ml}$ \\
\hline FT4 (free levothyroxine) & 10.45 & $9-19$ & $\mathrm{pmol} / \mathrm{l}$ \\
\hline Plasma calcitonin & 4.32 & $8.31-14.3$ & $\mathrm{pg} / \mathrm{ml}$ \\
\hline $\begin{array}{l}\text { ATPO (anti-thyroid } \\
\text { antibodies) }\end{array}$ & 0.25 & $0-5.61$ & $\mathrm{UI} / \mathrm{ml}$ \\
\hline $\begin{array}{l}\text { ATG (aAnti-thyroglobulin } \\
\text { antibodies) }\end{array}$ & 12.59 & $0-115$ & $\mathrm{UI} / \mathrm{ml}$ \\
\hline PTH (parathormone) & 28.73 & $15-65$ & $\mathrm{pg} / \mathrm{ml}$ \\
\hline $\begin{array}{l}25 O H D \\
\text { (25-hydroxyvitamin D) }\end{array}$ & 24.7 & $30-100$ & $\mathrm{ng} / \mathrm{ml}$ \\
\hline
\end{tabular}

\section{DISCUSSION}

The clue of the case is the fact that first pathological report suggested a malignant pheochromocytoma despite the fact that at that moment no metastasis was revealed at typical computed tomography evaluation with intravenous contrast. I (iodine) ${ }^{131}$ MIBG (meta-iodobenzylguanidine) scintigraphy was not available, neither during the 6-year period of follow-up. The first score applied to the tumour was PASS score of 8 based on capsular invasion, atypical mitotic count, tumour cell spindling in addition to $>3$ out of 10 mitotic account. In 2017, it became available GAPP score and we recalculated the tumour scoring. Based on moderate cellularity, the presence of capsular invasion in association with a Ki67 index of $10 \%$ at immunohistochemistry and hormonal balance showing a noradrenaline type, the grading was of 5 , meaning a moderately differentiated type (between 3 and 6) (12). At immunohistochemistry report, we also mention negative reaction for Melan A, S100 and positive for SYNAPTO and CROMO.

Other elements that are potentially useful for a malignancy profile, a part of identification of a metastasis, like gene mutations associated with highly aggressive profiles (for instance, certain types of succinyl dehydrogenase enzyme mutations) or imaging with suspected features were not identified $(13,14)$.

Other aspects of the case that worth to be mention include anomalies of glucose profile that were confirmed at diagnosis and normalized after surgery. It is well known that $50 \%$ of subjects with pheochromocytoma might associate this type of anomalies, which aggravate the overall picture of morbidity and mortality 
(15). Interestingly, the patient also experienced within the first year after adrenalectomy, a stoke episode, associating neurological complications that were remitted. The risk of stroke is, of course, higher pre-operatory, but certain persistent endothelial effects and lack of adequate control regarding the blood pressure values may contribute to further cardiovascular events (16). This chapter of pheochromocytoma complications also include cardiac events like acute damage of myocardial tissue and arrhythmia (17). Exceptionally, Takabuso syndrome has been described (18). Moreover, immediately after tumour manipulation during surgical procedure, hypotension, and cardiac arrest are described unless the patient's pre-operative and intra-operative preparation is adequately done (19). Approximately $20 \%$ of subjects with pheochromocytoma do not have high blood pressure; the risk of cardiovascular damage is closely related to hormonal excess which is rather associated with certain gene mutations, and less with the aggressively of the tumour (20). A mild vitamin D deficiency was also confirmed in our patient that most probably it is not related to the adrenal condition itself. The abdominal scans also identified kidney stones but the patient did not experience hypercalcemia or high parathormone levels, neither calcitonin, so a type $2 \mathrm{~A}$ multiple endocrine neoplasia syndrome was excluded.

\section{CONCLUSIONS}

Patients with a prior adrenalectomy for a pheochromocytoma need to be reconsidered in order to address the changes of scoring systems, thus to have a better prognostic score and an improvement of long term surveillance protocol. Reconsidering immunohistochemistry profile which was not a criterion of PASS score is essential in addition to re-asses the adrenaline versus noradrenaline secretor type that is regarded as a more severe prognostic. Overall, except for identifying the metastasis, no single criteria work as a definitive prognostic feature in this complex and challenging condition.

Conflict of interest: none declared Financial support: none declared

\section{REFERENCES}

1. Valea A, Carsote M, Ghervan C, Georgescu C. Glycemic profile in patients with acromegaly treated with somatostatin analogue. J Med Life. 2015;8(Spec issue):79-83.

2. Sandru F, Dumitrascu MC, Albu SE, Carsote $\mathrm{M}$, Valea A. Hyperpigmentation and ACTH - an overview of literature. Ro Med J. 2019;66(4):309-312.

3. Valea A, Ghervan C, Carsote M, Morar A, lacob I, Tomesc F, Po DD, Georgescu C. Effects of combination therapy: somatostatin analogues and dopamine agonists on $\mathrm{GH}$ and IGF1 levels in acromegaly. Clujul Medical. 2015;88(3):310-313.

4. Paduraru DN, Ion D, Carsote M, Andronic O, Bolocan A. Post-thyroidectomy Hypocalcemia - Risk Factors and Management. Chirurgia. 2019;114(5):564570.

5. Sandru F, Carsote M, Albu SE, Valea A, Petca A, Dumitrascu MC. Glucagonoma: From skin lesions to the neuroendocrine component (Review). Exp Ther Med. 2020;20(4):3389-3393.

6. Thompson LDR, Gill AJ, Asa SL, CliftonBligh RJ, de Krijger RR, et al. Data set for the reporting of pheochromocytoma and paraganglioma: explanations and recommendations of the guidelines from the International Collaboration on Cancer Reporting.Hum Pathol. 2021;110:83-97.
7. Yen K, Lodish M. Pheochromocytomas and paragangliomas. Curr Opin Pediatr. 2021 Aug 1;33(4):430-435.

8. Sbardella E, Grossman AB. Pheochromocytoma: An approach to diagnosis. Best Pract Res Clin Endocrinol Metab. 2020 Mar;34(2):101346.

9. Sandru F, Dumitrascu MC, Valea A, Albu SE, Dumitrascu A, Carsote M. Flush after unilateral adrenalectomy. Ro J Med Pract. 2020;15(1):101-4.

10. Valea A, Carsote M, Albu SE, Dumitrascu MC, Sandru F. From transitory erythema to phepocromocytoma. Ro Med J. 2019;66(4):412-5.

11. Sandru F, Carsote M, Valea A, Albu SE, Petca RC, Dumitrascu MC. Somatostatinoma: Beyond neurofibromatosis type 1 (Review). Exp Ther Med. 2020;20(4):3383-3388.

12. Juhlin CC. Challenges in Paragangliomas and Pheochromocytomas: from Histology to Molecular Immunohistochemistry. Endocr Pathol. 2021;32(2):228-244.

13. Barber B, Ingram M, Khan S, Bano G, Hodgson S, Vlahos I. Clinicoradiological manifestations of paraganglioma syndromes associate with succinyl dehydrogenase enzyme mutation. Insights Imaging. 2011;2(4):431-438.

14. Carsote M, Ghemigian A, Terzea D, Gheorghisan-Galateanu AA, Valea A. Cystic adrenal lesions: focus on pediatric population (a review). Clujul Medical. 2017;90(1):5-12.

15. Abe I, Islam F, Lam AK. Glucose Intolerance on Phaeochromocytoma and Paraganglioma-The Current Understanding and Clinical Perspectives. Front Endocrinol (Lausanne). 2020 Nov 26;11:593780.

16. Y-Hassan S, Falhammar H. Cardiovascular Manifestations and Complications of Pheochromocytomas and Paragangliomas. J Clin Med. 2020;9(8):2435.

17. Zhou J, Xuan H, Miao Y, Hu J, Dai Y. Acute cardiac complications and subclinical myocardial injuries associated with pheochromocytoma and paraganglioma. BMC Cardiovasc Disord. 2021 Apr 21;21(1):203.

18. Y-Hassan S, Falhammar $\mathrm{H}$. Pheochromocytoma- and paragangliomatriggered Takotsubo syndrome. Endocrine. 2019;65(3):483-493.

19. Mamilla D, Araque KA, Brofferio A, Gonzales MK, Sullivan JN, Nilubol N, Pacak K. Postoperative Management in Patients with Pheochromocytoma and Paraganglioma. Cancers (Basel). 2019 Jul 3;11(7):936.

20. Canu L, Parenti G, De Filpo G, Mannelli M. Pheochromocytomas and Paragangliomas as Causes of Endocrine Hypertension. Front Endocrinol (Lausanne). 2019 Jun 4;10:333. 